\title{
PANCREATIC PSEUDOCYSTS: OPTIMAL TIME OF SURGERY
}

\author{
Saša Dimić1, Milan Radojković2,3, Ivana Dimić4, Dušan Petrović1, \\ Aleksandar Karanikolić ${ }^{2,3}$
}

\begin{abstract}
Pancreatic pseudocysts occur as a complication of acute or chronic pancreatitis. Despite constant development of minimally invasive techniques, surgery is still the most important therapeutic option for these patients. An optimal time for pseudocyst operative treatment varies depending on the lesion cause, stage, and presence of complications. The aim of our study was to determine the importance of the time of surgery in relation to the pseudocyst type and stage for the treatment outcome. We conducted a retrospective analysis of medical records of 68 patients operated for pseudocysts at the Surgery Clinic, Clinical Center Nis. From among 50 patients that underwent elective surgery, external pseudocyst drainage was done in 6 due to its "immature", thin wall. Further, external drainage was performed in 15 urgently operated patients with complicated pseudocysts. The rest of the patients from both groups received an internal drainage procedure. There were no deaths. A controlled postoperative pancreatic fistula occured in 2 patients after elective internal drainage surgery and in 7 patients with complicated pseudocysts in whom urgent external drainage was done. Acute and chronic pseudocysts older than 6 to 8 weeks with formed mature capsule that do not show the tendency to resolve spontaneously require surgical or endoscopic drainage. Internal surgical drainage procedure should not be performed for immature and complicated pseudocysts with thin wall, which have to be treated with external drainage. An optimal time of surgery for pseudocysts may be crucial for the treatment success.
\end{abstract}

Acta Medica Medianae 2017;56(4):61-65.

Key words: pancreas, pseudocysts, surgery

${ }^{1}$ Surgery Department, Health Center, Kosovska Mitrovica, Serbia

${ }^{2}$ General Surgery Clinic, Clinical Center Niš, Serbia

${ }^{3}$ University of Nis, Faculty of Medicine, Niš, Serbia

${ }^{4}$ Primary Healthcare Center, Kosovska Mitrovica, Serbia

Contact: Milan Radojković

UI. Sestara Baković 14/28, 18000 Niš

e-mail: mida71@mts.rs

\section{Introduction}

Pancreatic pseudocysts (PSCs) are acquired cystic lesions of the pancreas that occur as a complication of acute (AP) or chronic pancreatitis (CP). The wall of PSCs consists of inflammatory or fibrous tissue, but without inner epithelial lining (Figure 1) (1). Although they originate from pancreatic tissue, their localization may also be extrapancreatic. When communicating with the pancreatic duct, they are filled with pancreatic juice (active PSCs) or otherwise, with a clear serous fluid without pancreatic enzymes. Their incidence depend on the incidence rates of $A P$ and $C P$ and therefore is constantly increasing. Further, the advancement of radiological imaging techniques makes this entity more frequently diagnosed than in the past.

Despite constant development of minimally invasive techniques (endoscopic and percuta ne-

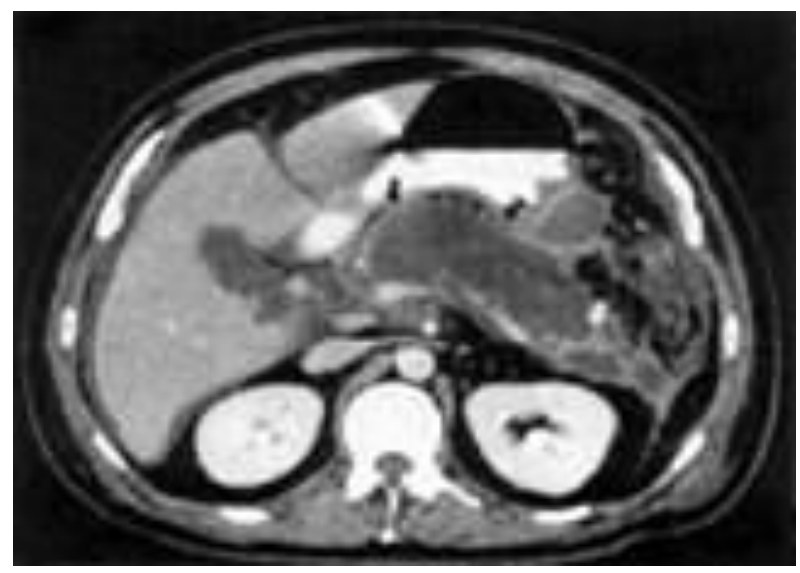

Figure 1. Large body and tail PSC after AP

ous), surgery is still the most important therapeutic option for these patients. It includes internal or external drainage procedures or a complete excision in selected cases. Surgery is man- 
datory for complicated PSCs (with abscess or wall necrosis, bleeding, perforation), large active PSCs, jaundice (compression of common bile duct), pain (main pancreatic duct of Wirsung stenosis), suspected malignancy and vomiting (compression of the stomach and/or duodenum) (2). The outcome of surgery depends mostly on the procedure timing. An optimal time for PSC operative treatment varies depending on the lesion cause (AP or CP), stage of PSC evolution, and presence of complications.

The aim of our study was to determine the impact of the time of surgery in relation to the PSC type and stage on the treatment outcome.

\section{Material and methods}

We conducted a retrospective analysis of available medical records of 68 patients operated for PSCs from january 1, 2013 to december 31, 2015 at the Surgery Clinic, Clinical Center Niš, Serbia. Patient demography is presented in Table 1. Fifty $(73.5 \%)$ patients underwent elective surgery at least 8 weeks after the radiological diagnosis of PSC with multi-slice computed tomography (MSCT), out of which 46 had post-AP and 4 had $\mathrm{CP}$-induced PSCs. The remaining 18 patients $(26.5 \%)$ required an urgent surgery for complicated PSCs: 14 with abscessed and 4 with perforated PSCs with consequent peritonitis during the course of AP. Demographic features of the patients, surgery type and time and postoperative complication rates were analyzed and compared. Pa-tients treated with percutaneous drainage proce-dures were excluded.

Table 1. Patient demography

\begin{tabular}{|c|c|c|c|c|}
\hline Overall 68 patients & No $(\%)$ & Mean age (range) & $\mathrm{AP}(\mathrm{No})$ & $\mathrm{CP}(\mathrm{No})$ \\
\hline Men & $41(60,3)$ & 43 yrs (27-77) & 37 & 4 \\
\hline Women & $27(39,7)$ & 51 yrs (24-78) & 27 & 0 \\
\hline Electively operated & $50(73,5)$ & $55 \mathrm{yrs}$ & 46 & 4 \\
\hline Urgently operated & $18(26,5)$ & $44 \mathrm{yrs}$ & 18 & 0 \\
\hline
\end{tabular}

Table 2. Operative treatment results.

\begin{tabular}{||c||c|c|c|c|c||}
\hline Patients (No) & $\begin{array}{c}\text { External drainage } \\
\text { procedure (\%) }\end{array}$ & $\begin{array}{c}\text { Internal drainage } \\
\text { procedure (\%) }\end{array}$ & $\begin{array}{c}\text { Pancreatic } \\
\text { fistula (\%) }\end{array}$ & $\begin{array}{c}\text { Alcoholic } \\
\text { pancreatitis }\end{array}$ & $\begin{array}{c}\text { Biliary } \\
\text { pancreatitis }\end{array}$ \\
\hline \hline Electively operated (50) & $6(12)$ & $44(88)$ & $2(4)$ & $30(60)$ & $20(40)$ \\
\hline Urgently operated (18) & $15(83)$ & $3(17)$ & $7(39)$ & $10(56)$ & $8(44)$ \\
\hline
\end{tabular}

\section{Results}

The results of operative treatment are presented in Table 2. From among 50 patients that underwent elective surgery, external drainage of the PSCs was done in $6(12 \%)$ due to their "immature", thin wall. Further, external drainage was performed in $15(83,3 \%)$ urgently operated patients with complicated PSCs. The rest of the patients from both groups received internal drainage procedure. There were no deaths. A controlled postoperative pancreatic fistula occurred in 2 (4\%) patients after elective internal drainage operative procedure and in 7 (39\%) patients with complicated PSCs in whom urgent external drainage was done. None of the patients with fistula experienced additional complications associated with pancreatic leakage, such as intraabdominal retention of the pancreatic juice, peritonitis, electrolyte imbalance or sepsis, and none of them required reoperation. The average hospital stay was significantly longer for patients with postoperative fistula compared to those with uneventful postoperative course (26 and 7 days, respectively), as expected.

\section{Discussion}

PSCs are among the most common pathological conditions in everyday surgical practice. The management of patients with PSCs is often complex and requires multidisciplinary approach and its success depends on various factors. According to the Atlanta Classification, these cystic lesions are divided into 4 groups: acute peripancreatic fluid collections without a granulomatous or fibrous wall (occuring during the onset of AP) (Figure 2), acute PSCs with a granulomatous or fibrous wall (occuring as a consequence of healed AP or trauma), chronic PSCs (consequence of CP) and pancreatic abscess (without or with some necrosis, with peripancreatic or extrapancreatic localization occuring as a consequence of pancreatitis or trauma) (3). Nealon and Walser proposed the classification based on the morphological condition of the Wirsung duct and the presence of communication between the main pancreatic duct and PSC in order to facilitate the choice of an optimal treatment method (4). PSCs develop in 5-16\% patients with AP and $20-40 \%$ of patients with CP $(5,6)$. These are most commonly diagnosed in pa- 


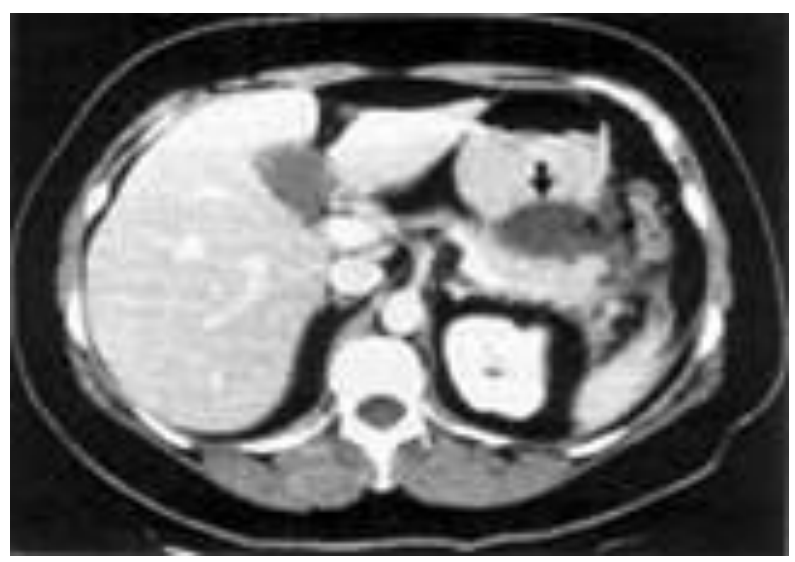

Figure 2. Acute fluid collection around the pancreatic tail without a formed wall occurring after AP.

tients with alcoholic HP (56-78\%), biliary AP (6$36 \%$ ) and postoperative (postinterventional) or posttraumatic AP (3-8\%) (7). These incidences and etiological distributions were also present in our study.

The diagnosis of PSCs most often requires the use of a number of diagnostic tools, such as percutaneous (US) or endoscopic echotomography (EUS), MSCT, nuclear magnetic resonance (MRI), endoscopic retrograde cholangiopancreaticography (ERCP), magnetic resonance cholangiopancreatography (MRCP) and laboratory. The basic diagnostic criterion is the presence of a well defined granulomatous or fibrous wall, except for acute liquid collections. On CT scans the PSC capsule or wall shows a contrast enhancement. The aim of the radiological imaging is to determine the basic morphological features of a PSC: its size, site, thickness and integrity of the wall, and presence of septa. Nevertheless, in approximately $10 \%$ of the patients, even after the diagnostic procedures, there still may exist a dilemma about the nature of the cyst (8) (Figure 3.).

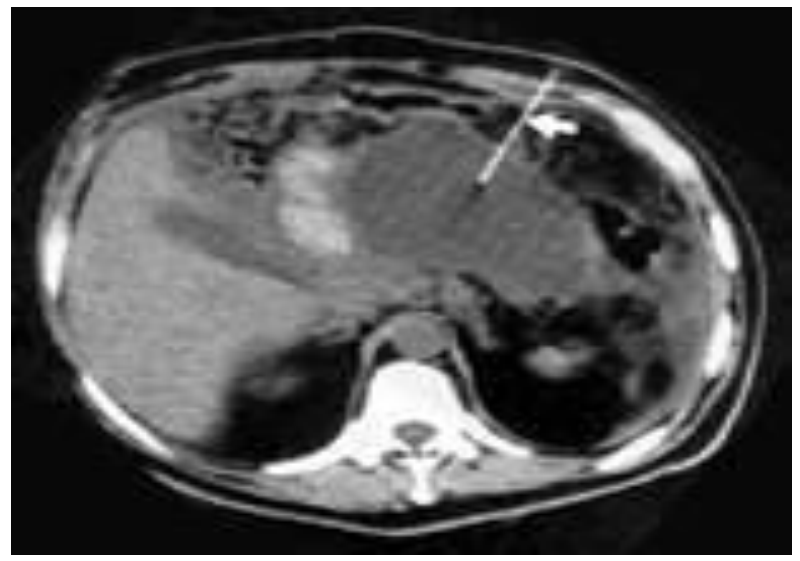

Figure 3. Percutaneous external drainage of large body and tail PSC.

Despite rapid development of minimally invasive techniques (endoscopic and percutaneous), surgery (open or laparoscopic) is still the most important therapeutic option for PSCs. The
University of Greifswald clinical algorithm uses size and localization of the cyst and the occurrence of complications as parameters for choosing the treatment modality: small cysts $(<5 \mathrm{~cm})$ without complications are observed for further growth/ regression or complications, but if the size exceeds $5 \mathrm{~cm}$ and/or complications occur the cyst has to be treated either surgically or endoscopically. Surgical treatment includes several modalities of internal drainage, ie. surgically created connection between the pseudocyst and a nearby digestive organ, such as pseudocystogastrostomy, pseudocystoduodenostomy or Roux-en-Y-pseudocystojejunostomy. Moreover, external surgical drainage or complete excision/resection may be performed in selected patients depending on the PSC size and localization.

The optimal time of surgery for PSCs depends on the cyst stage, i.e. the maturity and thickness of its wall which has to be consistent enough to hold the sutures and anastomosis to be created. In patients with CP-induced PSCS, the anastomosis may be performed immediately after the diagnosis, since it is assumed that the cyst wall is already well formed, mature and enough strong due to the chronicity of the underlying disease. However, choosing the optimal time of surgery for post-AP and posttraumatic PSCs may be much more challenging (9). The definitive diagnosis of acute PSCs is established only if the acute fluid collection persists for 4 to 6 weeks after the healing of AP and the development of a well defined capsule is confirmed on follow-up radiological imaging (10). Then the thickness, quality, ability to hold the sutures and susceptibility for anastomosis of the cyst wall is assessed. Premature surgery, while the capsule is still thin and flaccid, leads to the occurrence of an (un)controlled pancreatic leakage with possible additional complications such as peritonitis and sepsis. The relatively high rate of external drainage procedures for immature PSCs in $6(12 \%)$ of our patients who were operated electively indicates that the cyst maturation period in these cases was not long enough and the surgery was performed too early, although preoperative radiological imaging showed satisfactory thicknes of the wall and procedure was done 8 weeks after the AP healing and initial diagnosis of acute PSC. Uncomplicated acute PSC with thin, immature capsule requires delayed surgical treatment after the sufficient thickness of the cyst wall is confirmed on radiological imaging. On the contrary, a PSC complicated with massive necrosis, abscess, bleeding or perforation requires urgent surgery that includes extrenal drainage procedure or resection (if possible) due to immature, flaccid cyst capsule. Nevertheless, in 3 $(17 \%)$ of our patients with complicated PSCs internal drainage procedure was performed because the satisfactory thickness of the cyst wall was found intraoperatively. The incidence of well controlled pancreatic fistula in 9 patients was expected. The most frequent occurence of leakage in patients with external drainage of complicated PSC ( 7 patients) was also expected considering that complicated cysts did not have well formed 
fibrous capsule due to ongoing active inflammation, necrosis and/or abscess. The onset of pancreatic leak-age is associated with a longer mean hospital stay of these patients during the time needed for a complete controlled spontaneous regression of the fis-tula.

\section{Conclusion}

Surgery for PSCs may be challenging and associated with complications. Acute and chronic
PSCs older than 6 to 8 weeks, with a formed mature capsule, that do not show the tendency to resolve spontaneously, require surgical or endoscopic drainage. Internal surgical drainage procedure should not be performed for immature and complicated PSCs with a thin wall, which should be treated with external drainage. The optimal time of surgery for PSC may be crucial for the treatment success.

\section{References}

1. Horwitz JB, Lenobel MJ. Artificial hip prosthesis in acute and non union fractures of femoral neck: follow-up study of seventy cases. JAMA 1954; 155(6):564-7. [CrossRef] [PubMed]

2. McElfresh EC, Coventry MB. Femoral and pelvic fractures after total hip arthroplasty. J Bone Joint Surg 1974; 56(3):483-92. [CrossRef] [PubMed]

3. Sidler-Maier CC, Waddell JP. Incidence and predisposing factors of periprosthetic proximal femoral fractures: a literature review. Int Orthop 2015; 39(9):1673-82. [CrossRef] [PubMed]

4. Mitković M. Rezultati primene originalnih minimalno invazivnih hirurških metoda lečenja preloma. Acta Fac Med Naiss 2002; 19(3-4):167-78.

5. Milenkovic S, Mitković M, Micix I, Radenkovic M. Mitkovic's internal fixator - A new concept with sliding and compression along the neck and shaft of the femur for trochanteric and subtrochanteric fractures. Eur J Trauma 2002; 28(Suppl 1):208.

6. Lewis GS, Caroom CT, Wee $H$, Jurgensmeier $D$, Rothermel SD, Bramer MA, et al. Tangential bicortical locked fixation improves stability in Vancouver B1 Periprosthetic Femur Fractures: A biomechanical study. J Orthop Trauma 2015; 29(10):e364-70. [CrossRef] [PubMed]

7. Milenković S, Stanojlović M, Mitković M, Radenković $M$. Dynamic internal fixation of the periprosthetic femoral fractures after total hip arthroplasty. Acta
Chir Iugosl 2004; 51(3):93-6. [CrossRef] [PubMed]

8. Faschingbauer $M$, Reichel $H$, Bieger $R$, Kappe $T$. Mechanical complications with one hundred and thirty eight (antibiotic-laden) cement spacers in the treatment of periprosthetic infection after total hip arthroplasty. Int Orthop 2015; 39(5):989-94. [CrossRef] [PubMed]

9. Haddad FS, Duncan CP, Berry DJ, Lewallen DG, Gross AE, Chandler HP. Periprosthetic femoral fractures around well-fixed implants: use of cortical onlay allografts with or without a plate. J Bone Joint Surg 2002; 84(6): 945-50. [CrossRef] [PubMed]

10. Toogood PA, Vail TP. Periprosthetic fractures: A common problem with a disproportionately high impact on healthcare resources. J Arthroplasty 2015; 30(10):1688-91. [CrossRef] [PubMed]

11. Mont MA, Maar DC. Fractures of the ipsilateral femur after hip arthroplasty: a statistical analysis of outcome based on 487 patients. J Arthroplasty 1994; 9(5):511-9. [CrossRef] [PubMed]

12. Larson JE, Chao EYS, Fitzgerald RH. Bypassing femoral cortical defects with cemented intramedullary stems. J Orthop Res 1991; 9(3):414-21. [CrossRef] [PubMed]

13. Thukral R, Marya S, Singh C. Management of distal femoral periprosthetic fractures by distal femoral locking plate: A retrospective study. Indian J Orthop 2015; 49(2):199-207. [CrossRef] [PubMed] 


\title{
PSEUDOCISTE PANKREASA: OPTIMALNO VREME HIRURŠKOG LEČENJA
}

\author{
Saša Dimić ${ }^{1}$, Milan Radojković2,3, Ivana Dimić4, Dušan Petrović ${ }^{1}$, \\ Aleksandar Karanikolić2,3
}

\author{
${ }^{1}$ Zdravstveni centar Kosovska Mitrovica, Hirurško odeljenje, Kosovska Mitrovica, Srbija \\ ${ }^{2}$ Klinika za Hirurgiju, Klinički Centar Niš, Niš, Srbija \\ ${ }^{3}$ Univerzitet u Nišu, Medicinski fakultet, Niš, Srbija \\ ${ }^{4}$ Dom zdravlja, Kosovska Mitrovica, Srbija \\ Kontakt: Milan Radojković \\ Ul.Sestara Baković 14/28, 18000 Niš \\ e-mail: mida71@mts.rs
}

Pseudociste pankreasa nastaju kao komplikacija akutnog ili hroničnog pankreatitisa. Uprkos stalnom razvoju minimalno invazivnih procedura, hirurško lečenje je i dalje najvažnija terapijska opcija za ove bolesnike. Optimalno vreme za operaciju pseudociste zavisi od uzroka ciste, njenog evolutivnog stadijuma i prisustva komplikacija. Cilj našeg rada bio je da utvrdimo značaj vremena hirurškog lečenja u odnosu na tip i stadijum pseudociste za uspeh lečenja. Sproveli smo retrospektivnu analizu medicinske dokumentacije 68 bolesnika operisanih zbog pseudociste pankreasa na Klinici za hirurgiju Kliničkog centra u Nišu. Od 50 elektivno operisanih, kod šestoro je urađena eksterna drenažna procedura zbog nezrelog, tankog zida ciste. Takođe, eksterna drenaža pseudociste je sprovedena kod 15 urgentno operisanih bolesnika sa komplikovanim pseudocistama. Kod ostalih bolesnika iz obe grupe primenjena je unutrašnja drenažna procedura. Nije bilo smrtnih ishoda. Kontrolisana postoperativna pankreasna fistula javila se kod dva bolesnika nakon elektivne unutrašnje drenažne operacije i kod sedam bolesnika sa komplikovanom pseudocistom kod kojih je sprovedena urgentna spoljašnja drenaža. Akutne i hronične pseudociste starije od 6 do 8 nedelja sa formiranom zrelom kapsulom, koje ne pokazuju tendenciju spontane regresije, zahtevaju hiruršku ili endoskopsku drenažu. Unutrašnja hirurška drenažna procedura se ne treba primenjivati kod nezrelih i komplikovanih pseudocista sa tankim zidom, već ovakve lezije treba rešavati spoljašnjom drenažom. Optimalno vreme operacije pseudociste pankreasa može biti ključno za krajnji ishod lečenja.

Acta Medica Medianae 2017;56(4):61-65.

Ključne reči: pankreas, pseudociste, hirurško lečenje 